Ctudenckie Koło Naukowe Specja- listów Informacji (dalej: KNSI), działające przy Instytucie Informacji Naukowej i Bibliologii UMK (dalej: IINiB UMK), zrzesza studentów zainteresowanych szeroko pojmowaną informatologią, a także jej dziedzinami pokrewnymi. Wynika to z głównego celu Koła - dążenia do naukowego rozwoju jego członków, m.in. poprzez udoskonalanie umiejętności dotyczących pozyskiwania, przetwarzania i zarządzania informacją, wspieranie samokształcenia członków, stwarzanie warunków umożliwiających członkom pracę naukową i podejmowanie inicjatyw oraz prezentowanie działań podejmowanych przez Koło.

Historia KNSI sięga końca lat 70. XX wieku. Od tego czasu Koło przeszło liczne transformacje, zmiany profilu działalności, a co za tym idzie - opiekuna naukowego oraz nazwę. W roku akademickim 2013/2014 funkcję opiekuna pełniła dr Małgorzata Kowalska. Zmianie uległ również Zarząd Koła. Po ponad rocznej kadencji zakończyli swoją pracę w KNSI Marcin Karwowski (przewodniczący od lutego 2012 r.), Agata Bernaś (wiceprzewodnicząca od czerwca 2012 r.) oraz Natalia Kraińska (pełniąca funkcje skarbnika i sekretarza również od lutego 2012 r.). Ich miejsce zajęły Weronika Dziadul (przewodnicząca), Weronika Korga (zastępca) i Katarzyna Fryszkowska

\section{Działalność Koła Naukowego Specjalistów Informacii w roku akademickim 2013/2014}

DOI: http://dx.doi.org/10.12775/TSB.2014.032

(sekretarz/skarbnik), które zostały wybrane na Walnym Zebraniu Koła w maju 2013 r.

Plany KNSI na kolejny rok akademicki pokrywały się z działalnością Koła w latach poprzednich. Można było zaliczyć do nich udział (zarówno czynny, jak i bierny) w konferencjach naukowych, publikację artykułów naukowych członków KNSI, organizację ogólnopolskiej konferencji bibliologicznych kół naukowych (co staje się tradycją Koła) oraz rozwój członków Koła, m.in. poprzez uczestnictwo w różnego rodzaju warsztatach. Ponadto, istotne stało się nawiązanie współpracy między specjalistami informacji a prasoznawcami, członkami Prasoznawczego Koła Naukowego (dalej: PKN), również działającego przy IINiB UMK. Dzięki temu możliwe było połączenie sił zarówno przy organizacji konferencji (KNSI), jak i przy wydawaniu przez PKN pisma studenckiego „Między Regałami” - członkowie KNSI są autorami licznych tekstów w tym 
piśmie. Dla obu stron okazało się to korzystnym posunięciem.

Jak już wspomniano, członkowie Koła pragną rozwijać się na różnych płaszczyznach. Dlatego właśnie już na początku roku akademickiego (18 i 19 października 2013 r.) trzy przedstawicielki KNSI uczestniczyły w warsztatach „Open Access. Wolny dostęp do nauki" ${ }^{1}$. Na dzień pierwszy przypadły głównie wykłady na temat wolnego dostępu - narzędzi, jakimi się posługuje i możliwości, jakie oferuje. Drugiego dnia warsztatów omawiane były możliwości promowania Open Access na polskich uczelniach.

Niecały miesiąc później miało miejsce kolejne wydarzenie, w którym aktywny udział brali przedstawiciele Koła. 15 listopada 2013 r. cztery członkinie zaprezentowały referaty na X Ogólnopolskiej Konferencji Studenckich Kół Naukowych „Informacja w świecie współczesnej komunikacji", zorganizowanej przez Koło Naukowe Studentów Informacji Naukowej i Bibliotekoznawstwa Uniwersytetu Jagiellońskiego. Ze względu na rozległą tematykę konferencja została podzielona na 4 sesje. Podczas pierwszej z nich, o nazwie „Chaos informacyjny”, zaprezento-

1 Zob. Ruszyły warsztaty o Open Access dla studentów i doktorantów! [online] [dostęp 31 października 2014]. Dostępny w World Wide Web: http://centrumcyfrowe.pl/ruszyly-warsztaty-o-open-accessdla-studentow-i-doktorantow/. wały się 3 członkinie Koła: Patrycja Nowik wygłosiła referat pod tytułem „Internetowy natłok informacji”, a Jagoda Rycharska i Dorota Zmudzińska wystąpiły z referatem „O szumie informacyjnym i warkocie włączonego silnika". Z kolei Weronika Dziadul, w sesji zatytułowanej „Sposoby i narzędzia organizacji wiedzy", zaprezentowała prelekcję pt. „Naukowy crowdsourcing", która została nagrodzona drugim miejscem w konkursie na najlepsze wystąpienie konferencji.

Po krakowskiej konferencji odbyła się kolejna, tym razem w Katowicach. 5 grudnia 2013 r. w VII Ogólnopolskiej Konferencji Studenckich Kół Naukowych Bibliotekoznawców pod hasłem „Czytelnik - odbiorca - użytkownik informacji w procesie kształtowania kultury czytelniczej i informacyjnej" wystąpiły z referatami Jagoda Rycharska i Weronika Korga. Po konferencji w Katowicach nastąpiła trzymiesięczna przerwa, a raczej zbieranie sił i przygotowania do organizacji własnego przedsięwzięcia, jakim była Ogólnopolska Konferencja Studenckich Kół Naukowych „Architektura i wizualizacja informacji: kontekst - zawartość użytkownicy - narzędzia”. Odbyła się ona 7 marca 2014 r. w sali Rady Wydziału Collegium Humanisticum. W jej obradach udział wzięli prelegenci z m. in. z Bydgoszczy, Lublina i Krakowa. Silne było również toruńskie przedstawicielstwo. Z referatami wy- 
stąpili mgr Agata Bernaś, mgr Marcin Karwowski i mgr Piotr Rudera oraz reprezentujące organizatorów - Weronika Dziadul, Jagoda Rycharska i Anna Hołowko. Konferencja była podzielona na sesje tematyczne oscylujące wokół zagadnień postrzegania kultury informacyjnej, jej badania oraz kształtowania. Interesujące referaty kilkunastu prelegentów, dyskusje po każdym z bloków tematycznych i pozytywne opinie stanowiły doskonały impuls do tego, by organizacja własnych konferencji na stałe wpisała się w nurt działalności Koła.

Pracowicie rozpoczęty marzec 2013 roku równie pracowicie zakończył się dla reprezentującej Koło Weroniki Dziadul, która 21 marca reprezentowała KNSI w Lublinie na Międzynarodowej Studencko-Doktoranckiej Konferencji Naukowej pt. „Informacja: jakość, ilość, wartość”, prezentując referat „Google, broń przeciwko społeczeństwu”. Z kolei miesiąc później (27 kwietnia), na V Ogólnopolskiej Bibliologicznej Konferencji Studenckich Kół Naukowych pod nazwą „Sen o bibliotece. Próba diagnozy jej współczesnych zadań i funkcji” w Bydgoszczy swoje referaty zaprezentowały Jagoda Rycharska („Udostępnianie informacji publicznej, jako usługa biblioteki - analiza różnych typów bibliotek) i Anna Hołowko („Mała biblioteka - lepsza biblioteka").
Wraz ze zbliżająca się letnią sesją egzaminacyjną oraz nadejściem końca roku akademickiego zakończyły się wyjazdy na konferencje. Nie oznaczało to jednak braku aktywności członków KNSI. Nadal trwały prace nad artykułami do periodyku „Między Regałami”. Warto wspomnieć, że w czterech numerach tego pisma, które zostały wydane w minionym roku akademickim, ponad połowę artykułów napisali właśnie przedstawiciele Koła. Ponadto, w dniach 15 i 16 kwietnia członkowie KNSI brali udział w nagrywaniu spotu reklamowego, promującego IINiB UMK i kierunek zarządzanie informacją i bibliologia ${ }^{2}$.

Udało się również zorganizować dwudniowy wyjazd do Starogardu Gdańskiego, gdzie zarówno przedstawiciele KNSI, jak i również wspomnianego wcześniej PKN wzięli udział w następujących warsztatach coachingowych: „Mapa marzeń - mapa celów”, „Zarządzanie czasem”, „Zarządzanie domowym budżetem" oraz „Metaprogramy”. Wyjazd był kontynuacją cyklu zajęć prowadzonych przez mgr. Marcina Karwowskiego, rozpoczętego już w maju warsztatami motywacyjnymi. Dzięki takim zajęciom

${ }^{2}$ Efekty można obejrzeć pod ad-resem: Film promujący ofertę Instytutu INiB $U M K$ [online] [dostęp 31 października 2014]. Dostępny w World Wide Web: http:// www.youtube.com/watch?v=31 NAf_kgxw A\&feature=youtu.be. 
członkowie Koła mieli możliwość rozwoju tzw. kompetencji miękkich, tak istotnych dziś dla pracodawców, jak i rozwoju osobistego.

W roku akademickim 2013/2014 zamknięto serwis internetowy WERSALIK (platforma Koła rozwijana od 2007 r.), a relacje $\mathrm{z}$ aktualnych wydarzeń zaczęto udostępniać poprzez fanpage w serwisie Facebook.

Działania KNSI w roku akademickim 2013/14 były poniekąd kontynuacją wcześniejszych przedsięwzięć. Istotnym wyzwaniem było zapewnienie członkom Koła możliwości rozwoju własnych umiejętności i zainteresowań naukowych. Udział w licznych konferencjach pozwolił na doskonalenie umiejętności prezentacji oraz nawiązanie międzyuczelnianych znajomości, warsztaty coachingowe - na zgranie zespołu, a przygotowywanie artykułów do studenckiego pisma - na realizację ambicji pisarsko-dziennikarskich.

\section{Weronika Korga}

studentka I roku uzupełniających studiów magisterskich na kierunku zarządzanie informacją i bibliologia
$\mathrm{W}$ dniach 1-2 lipca 2014 r. na Wydziale Matematyki i Informatyki Uniwersytetu Mikołaja Kopernika w Toruniu (dalej: WMiI UMK) odbyła się jedenasta edycja konferencji „Informatyka w Edukacji" (dalej: IwE). Organizatorami tegorocznej edycji był WMiI UMK wraz z kujawsko-pomorskim oddziałem Polskiego Towarzystwa Informatycznego. Jest to konferencja odbywająca się cyklicznie raz $\mathrm{w}$ roku. W kolejnych jej edycjach bierze udział ponad 300 uczestników reprezentujących instytucje sektora edukacyjnego z całej Polski. Tegorocznej jedenastej konferencji IwE przyświecało hasło przewodnie „Informatyka dla wszystkich od najmłodszych lat", które znalazło przełożenie $\mathrm{w}$ prezentowanych

\section{Konferencja "Informatyka w Edukacii" (Toruń, 1-2 lipca 2014 r.)}

DOI: http://dx.doi.org/10.12775/TSB.2014.033

referatach, a także przygotowanej przez organizatorów ofercie warsztatowo-seminaryjnej.

Konferencja została podzielona na cztery sesje plenarne - po dwie każdego dnia. W godzinach popołudniowych zaplanowane zostały bloki warsztatowo-seminaryjne. Każdy uczestnik konferencji otrzymał przed wejściem na salę obrad wydrukowany tom monografii z wykładami i materiałami 